\title{
Pre-Service Teachers' reflections in a virtual learning community: a praxeological study
}

Primer semestre de 2022 - pp. 221-240 Segunda época

N.
Reflexiones de

los profesores en

formación en una

comunidad virtual de

aprendizaje: un estudio

praxeológico
Reflexões dos

professores em

formação em uma

comunidade virtual de

aprendizagem: um estudo

praxeológico estilos

cognitivos

Ángela María Gamboa González* https://orcid.org/0000-0003-1128-4910

Catalina Herrera Mateus** https://orcid.org/0000-0002-9703-8608

Para citar este artículo

Gamboa-González, A. M. y Herrera-Mateus, C. (2022). Pre-Service Teachers' Reflections in a Virtual Learning Community: A Praxeological Study. Folios, (55).

https://doi.org/10.17227/folios.55-11912

Magíster en enseñanza de lenguas extranjeras. Universidad de La Salle.

Correo:agamboa@unisalle.edu.co

* Magíster en educación. Corporación Universitaria Minuto de Dios.

Correo: catalina.herrera@uniminuto.edu 


\title{
Abstract
}

This paper presents a praxeological study that analyzes pre-service teachers' reflections about their beliefs in teaching, English language teaching theories, and experiences as teachers. These reflections were shared in a vLc (Virtual Learning Community) to promote pre-service teachers' reflection in three moments: in, on, and for action. The participants were 25 pre-service teachers from a bachelor's program in English as a foreign language teaching at a private university in Bogotá, Colombia. The data collected came from the participants' responses, lesson plans, video recordings of their classes shared in the VLC, and a focus group. The results indicated that by reflecting on different moments of the teaching practice and sharing experiences with other classmates, pre-service teachers became more conscious about language teaching theories, their implementation, their actions, and decisions in the classroom. However, there is a need to promote deeper levels of reflection, in which pre-service teachers interpret and understand what happens in their practice better, from a critical point of view and in light of the theory and the reality of the school.

\section{Keywords}

reflective practice; teaching practice; virtual learning community; pre-service teachers

\section{Resumen}

\begin{abstract}
Este artículo presenta un estudio praxeológico que analiza las reflexiones de los docentes en formación, específicamente, de sus creencias sobre la enseñanza, lo que piensan acerca de las teorías para enseñar inglés y su primera experiencia como maestros. Estas reflexiones fueron compartidas en una comunidad virtual de aprendizaje (cva) diseñada para promover la reflexión de los docentes en formación en tres momentos: en, sobre y para la acción. Los participantes fueron 25 docentes en formación de un programa de licenciatura en Inglés como lengua extranjera en una universidad privada en Bogotá, Colombia. Se recopilaron datos de las respuestas de los participantes, planeaciones, videos de sus clases compartidas en la cva y un grupo focal. Los resultados indicaron que al reflexionar en diferentes momentos de la práctica docente y compartir experiencias con otros compañeros, los docentes en formación fueron más conscientes de las teorías de enseñanza de lenguas y su aplicación, sus acciones y decisiones en el aula. Sin embargo, es evidente la necesidad de promover niveles más profundos de reflexión, de manera que los docentes en formación interpreten y entiendan mejor lo que sucede en su práctica desde un punto de vista crítico y a la luz de la teoría y la realidad de la escuela.
\end{abstract}

\author{
Palabras clave \\ práctica reflexiva; práctica docente; comunidad virtual de aprendizaje; docentes en formación
}

\section{Resumo}

Este artigo apresenta um estudo praxeológico que analisa as reflexões dos professores em formação, especificamente, de suas crenças sobre o ensino, o que pensam sobre as teorias para o ensino de inglês e sua primeira experiência como professores. Estas reflexões foram compartilhadas em uma comunidade virtual de aprendizagem (cva) projetada para promover a reflexão dos professores em formação em três momentos: em, sobre e para a ação. Os participantes foram 25 professores em formação de um programa de licenciatura em inglês como língua estrangeira em uma universidade privada em Bogotá, Colômbia. Os dados foram coletados a partir das respostas dos participantes, planejamentos, vídeos de suas aulas compartilhadas na cva e um grupo focal. Os resultados indicaram que ao refletir sobre diferentes momentos da prática docente e ao compartilhar experiências com outros colegas, os professores em formação ficaram mais conscientes das teorias do ensino de línguas e sua aplicação, suas ações e decisões em sala de aula. No entanto, é evidente a necessidade de promover níveis de reflexão mais profundos, para que os formandos interpretem e entendam melhor o que acontece na sua prática desde um ponto de vista crítico e à luz da teoria e da realidade da escola.

\section{Palavras chave}

prática reflexiva; prática docente; comunidade virtual de aprendizagem; professores em formação 


\section{Introduction}

This article reports the findings of the second stage of a project aimed at showing pre-service teachers' beliefs about teaching and learning English before their first teaching practicum, and how those beliefs remained, changed, or disappeared once pre-service teachers faced English language classes. According to the autobiographical narratives written by pre-service teachers as part of the first stage of this first project presented by Gamboa et al. (2017), pre-service teachers had some difficulties linking their beliefs and theories about language teaching methodology to their practice. As a result, they had some trouble explaining their actions and decisions. Additionally, even after they have learned certain methodologies or didactic approaches, they often mix them up in their own practice.

Those insights have led us to focus our attention on pre-service teachers' beliefs about language teaching, and analyze them, as being aware of what pre-service teachers believe, know, and do is fundamental to understanding their actions and decisions while they plan and teach. Thus, a second stage of the project was proposed in the research study called "Reflective Practice about Professional Work and Beliefs about Teaching", in an undergraduate ELT program at a private university in Bogotá, Colombia.
In this second stage, pre-service teachers had the opportunity to write their own reflections while participating in a virtual learning community (VLC), emphasizing different scenarios and moments of their first teaching practicum.

Several studies have shown that reflective practice is currently the main element in pre-service teachers' professional development, as it is considered a way to improve teaching quality and make teachers aware of their actions in the classroom. There are different reflective activities, including action research, teaching journals, concept mapping, teacher development groups, and classroom observations (Farrell, 2013a). Of these, journals are the most common approach (Alirio Insuasty \& Zambrano Castillo, 2010; Hoyos Ensuncho et al., 2017; Lee, 2007; Morrison, 1996), since they let pre-service teachers' record their thoughts, beliefs, and actions on paper or a computer screen. The teachers can also review their journals later and think more deeply about them. Other studies have implemented reflective activities such as self-observation (Viáfara, 2005), interviews (Cote Parra, 2012), portfolios (Bozu \& Imbernon-Muñoz, 2009), and observations (Zahid \& Khanam, 2019). Most of these studies either promote self-reflection, or a dia- 
logue with pre-service teachers' trainers about their beliefs and actions in the classroom, or address how to solve technical problems regarding discipline, developing activities, and classroom management.

Nevertheless, these reflective activities do little to promote interaction among pre-service teachers, so they miss the opportunity to share their ideas and opinions about language teaching methodology with their peers. To solve this problem, the aforementioned reflective activities can be developed virtually, promoting interaction among pre-service teachers while taking advantage of technological tools and utilizing EEL: "everywhere \& every time learning" (Becerra-Traver \& Gutiérrez-Esteban, 2016, p. 74). Indeed, many studies concerning the use of technology to support learning have been developed over the years (Becerra-Traver \& Gutiérrez-Esteban, 2016; Coll et al., 2008; Gairín, 2006; Raposo-Rivas \& Escola, 2016). They propose the implementation of virtual learning communities (VLCs) as a possibility to interchange ideas, opinions, experiences, and thoughts about topics of common interest in an internet-based environment, and agree on their usefulness to build knowledge collaboratively (Murua et al., 2014).

Keeping this in mind, the researchers created a VLC in a cloud-based web development platform. It was designed with three different sections, in which pre-service teachers found questions based on the three moments of reflective practice proposed by Farrell (2013) and Schön (1987): in-on-for action, to promote interaction among practitioners and to encourage them to reflect on their own beliefs about teaching a foreign language, their experiences during their first practice, and their daily practices in the classroom.

\section{Conceptual Framework}

\section{Reflective Practice}

Reflective practice is a current well-known activity in teacher training programs: it improves teaching by making pre-service teachers aware of what they are doing in the teaching practice, so they can identify strategies, activities, methods, etc. that contribute to students' learning. In the same way, Farrell $(2013 ; 2018)$ suggested that reflective practice examines what pre-service teachers are doing in the classroom and why they are doing it, as well as how teaching beliefs are evident during the practice. Reflective practice should be a daily activity for pre-service teachers, since in every class they face situations that require analysis in terms of appropriateness and coherence with their beliefs and students' needs.

In addition, reflective practice engages pre-service teachers in exploring "their experiences in order to lead to new understandings and appreciation" (Walsh \& Mann, 2015, p. 352), which suggests they are able to create their own knowledge and re-construct their beliefs about language teaching based on what they have experienced previously, thus improving the teaching conditions to guarantee students' learning. However, one of the difficulties pre-service teachers face when they reflect on their own beliefs and actions during practice is that their reflection is rarely conscious and systematic, as they just look for immediate solutions to the problems presented. Accordingly, Farrell (2013) recommended that when implementing reflective practice, pre-service teachers should consciously and critically analyze their beliefs, become responsible for their actions, systematically collect evidence to improve their teaching, and make more aware decisions.

One model to promote reflective practice was proposed by Schön (1987). In this model, reflection takes place in two moments of the teaching practice: in action and on action. Reflection in action takes place during the class and its purpose is to reflect immediately on technical issues, in order to restructure a situation in the classroom to solve or face it successfully. As this reflection occurs while pre-service teachers are teaching, they must quickly assess the situation, and then use their knowledge, beliefs, and experience to make the best decision. On the other hand, reflection on action refers to reflection taking place after the class. Here, pre-service teachers might think deeply about and critically 
analyze the actions and problems they faced during the class. This helps them understand why situations happen and re-structure their beliefs and future actions. However, this reflection requires autonomy and self-regulation by the pre-service teachers, many of whom are not used to reflecting in this way, at least unless they are guided by a teacher trainer.

To supplement these two moments of reflection, Farrell (2015) proposed a third moment: for action. This reflection happens before the class and its purpose is to plan future actions, using what was learned during and after the class. It could be said that reflection for action happens while pre-service teachers are planning, but they bear in mind the knowledge and experiences they acquired in the previous reflective moments. Figure 1 summarizes the three moments of reflective practice.

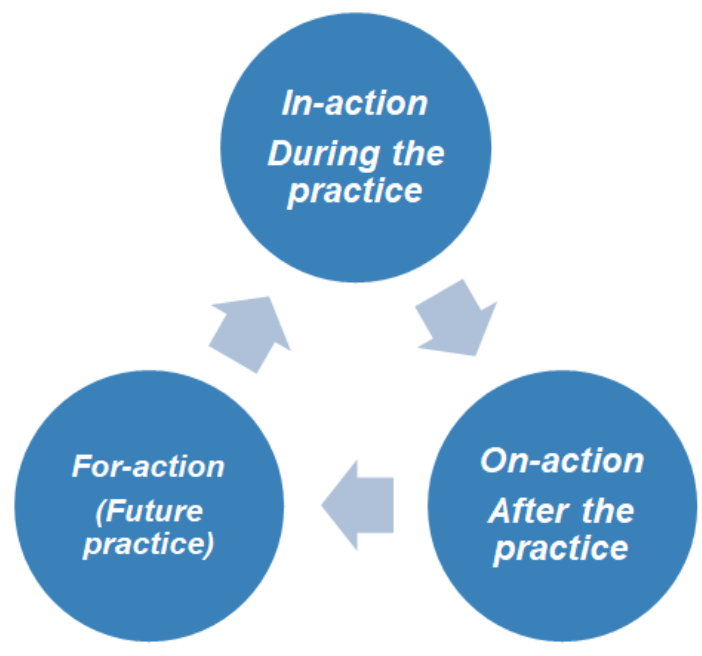

Figure 1.

Reflective practice moments

Note: The three reflective moments were implemented in the VLC

As can it be seen, these three moments of reflection prompt pre-service teachers to construct and reconstruct their beliefs and knowledge about language teaching methodology all the time, and to be more conscious of their actions. However, as Farrell (2018) and Walsh and Mann (2015) have claimed, the difficulty with most reflection models and activities is that they are typically done individually, and they focus on problems regarding classroom management and the usefulness of activities presented in the class rather than on professional or institutional concerns.

\section{Virtual Learning Communities}

In order to introduce the concept of virtual learning communities, it is necessary to explain initially what virtual communities are. Gairín (2006) stated that these communities exist thanks to technological advances and the different kinds of interaction (information and communication technologies-ICT) that the internet provides. In this sense, they can be understood as "spaces for interaction, communication, exchange of information or meetings associated with the possibilities offered by ICT to create a virtual environment-from the e-mail to the most complex content management systems based on internet-" (Coll et al., 2008, p. 308). Members of these communities only get in touch through the virtual environment they have created to interact and communicate.

According to Coll et al. (2008), virtual communities-depending on their objectives- can be classified into three different levels: virtual interest communities, virtual participation communities, and virtual learning communities. Virtual interest communities allow the participants to obtain information about any topic of interest, no matter the place or time. Additionally, people in these communities demonstrate an interest in interacting with others to communicate, ask for help or support, keep updated, share opinions about certain topics-even if they do not have the same point of view-, or just to have a shared space related to the same interests and preferences (Coll et al., 2008; Gairín, 2006). Virtual participation communities aim at making members get involved in the community and participate actively in its development through the different opportunities provided to exchange information. Furthermore, these communities are also created to generate solutions to a specific situation, taking into account the participants' contributions. 
Finally, virtual learning communities are defined by Gairín (2006) as "a set of people or institutions connected through the network that have as their target a determined content or learning task" (p. 56). Similarly, Coll et al. (2008) stated that members of these communities develop different activities, strategies, plans, and roles in order to achieve the main objective-in this case, learning. In fact, virtual learning communities are not only created to exchange information about common interests or to communicate with others, but they take advantage of the resources offered by the virtuality to promote learning. In this type of community, one person is in charge of guiding the learning process and has the responsibility to help the rest of the members achieve the learning goals proposed. This person is known as a teacher, tutor, or coordinator (Coll et al., 2008).

Gairín (2006) pointed out that when constructing virtual learning communities, it is necessary to consider at least three elements: the model of the educational intervention chosen, the type of virtual learning community, and the characteristics of the learning environment. The author further asserted that a virtual learning community needs to be part of a project which has a purpose to impact society or the specific context where it was developed, and that its proposed topics and contents need to be appropriate for the members and their needs (Gairín, 2006).

\section{Methodology}

This research study was conducted following the principles of praxeology as a research paradigm. The focus of this project was the pre-service teachers' reflections about their own beliefs, knowledge, and practice. Juliao (2011) defined praxeology as a research paradigm where a practice is investigated through analyzing the actions of the practitioners as professionals. To do so, Juliao (2011) proposed four stages: see, judge, act, and prospective.

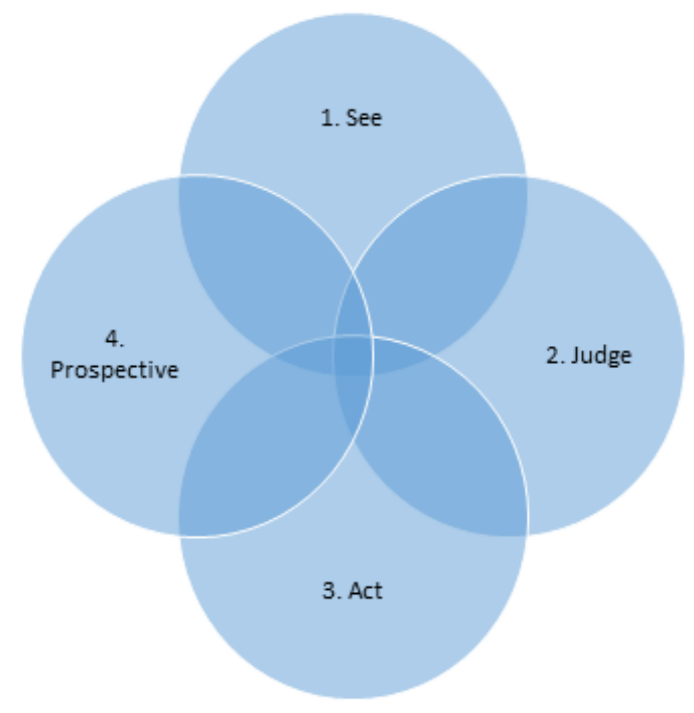

Figure 2. The praxeological model

Source: Taken from Juliao (2012)

The first stage, "see," attempts to see and analyze what is happening in the practice through the analysis of observations, documents, evaluations, state of the art, and so on. The analysis allows us to determine a problem, and in this sense, comprehend, decode, and confront a problem in the practicum.

Once the problem is identified, the researcher centers on "judging" the information, with the purpose of interpreting the practice and identifying the possible causes of the difficulties evidenced in it (Juliao, 2011) which can be of three types: historical, structural or relevant (see table 1). 
Table 1. Types of causes

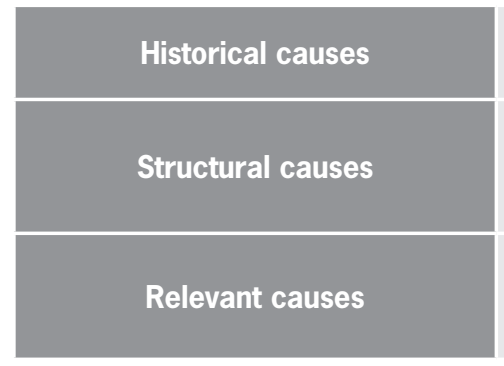

Past experiences explain current situations in the practice.

They explain how the practice is related to the educational system.

They account for the factors that surround the practice in a specific period of time.

Note: Difficulties in the practice might be the result of one of the causes proposed by Juliao (2011)

Source: Own Creation

After determining the causes of the problem, Juliao (2011) proposes the act stage, whose aim is to put into action an efficient and effective strategy or plan to improve the practice. They are mainly reflective activities and or scenarios created to enrich the practitioner/teacher practice and knowledge. Moreover, in this stage, the pre-service teachers or practitioners have the chance to know more about themselves, the classroom and their students, and use different tools and theories to enhance their practice.

Lastly, Juliao (2011) suggests a prospective stage, which intends to assess the plan or strategy implemented in the previous one, in order to recognize what was learned during the process, and take new actions to improve the practice one more time. Additionally, this stage helps the participants to assess their actions during the practice and discuss and criticize theories in the light of their own practice.

As it can be seen, praxeology is cyclical and never ends. It allows pre-service teachers a constant reflection about their own practice to do it more favorable each time. Additionally, praxeology empowers a systematic reflection that allows pre-service teachers to collect information about their own practice to go back and forth and contrast it, so they can determine what needs to be worked on.

\section{Praxeology phases}

In the following lines, we will describe the activities carried out in each of the praxeology phases. Beginning with the see phase, the autobiographical narratives written by pre-service teachers before and after their first teaching practice were analyzed. Initially, they were asked to write about their experiences as language learners, and their visions about learning and teaching. Once they finished their practice, they wrote their narratives again, this time about the experiences they had had as teachers, and, once again, about their views regarding learning and teaching. Some of the questions that guided two autobiographical narratives are summarized in table 2. 
Table 2. Questions for the autobiographical narratives

\section{Questions before the practicum}

1. Describe the most remarkable teachers and professors you have had (school/university): characteristics, the way they influenced you (positively or negatively), what you learnt from them, what you would—or would not-imitate from them.

2. Describe meaningful language learning situations or activities you experienced (positive or negative). Write how you felt and what you think of them. Would you repeat them? Why? If they were negative, how would you make them better?

3. When did you decide to become a language teacher? Why? Write if someone influenced you, how did you make the decision? Was it a right decision?

4. Write what you think about teaching a language, what approaches/methods/strategies you would like to use, what changes you think you can do in the language teaching profession.

\section{Questions after the practicum}

1. Describe the way you promote the use of L2 in the classroom. Is it different from the way your previous teachers did it?

2. Describe the way your students are learning the foreign language. Is it similar to the way you learnt it? Could you affirm that it is the best way to learn? Are you promoting positive experiences for your students' learning process? Which ones?

3. Could you teach the language using the materials, resources and methodologies you considered appropriate to promote learning? If not, what obstacles impeded it? Are they the best way to teach a foreign language? Were they innovative? Does this way to teach confirm your initial belief about teaching?

Source: Own Creation

The examination of those documents showed that some of the beliefs and conceptions they had about language teaching and learning were not evidenced in their practice. Likewise, even though they remembered some aspects about language teaching methodology theories, but they did not apply them in their practice, and most of the decisions they make and the activities they develope are based on their experiences as language learners (Gamboa et al.,2018). This was corroborated by some previous studies (Hennissen et al., 2017; Tilson et al., 2017), in which the teachers' trainers identify that pre-service teachers had the same problem in their practice.

The findings emerging from the see-phase were "judged" to find why pre-service teachers had the difficulties mentioned previously. Historical and relevant causes were identified. Regarding the historical ones, positive and negative experiences as language learners are the basis of the pre-service teachers' system of beliefs, and the first source they use when planning and developing classes, leaving aside most of the theory learned in their training. In relation to the relevant causes, the researchers perceived a lack of reflection about the language teaching methodologies, techniques, and strategies pre-service teachers implement in their practice.

To solve such problems, in the act-phase a vLC was designed. The main objectives of the VLC were to promote reflection on their own practice, especially about the language teaching methodology they implement, and to enrich their knowledge and practice based on the analysis and discussion with other colleagues.

In the VLC the three reflective moments mentioned previously (in-action, on-action, and for-action) were applied in three scenarios. In the first one, based on a hypothetical situation, participants analyzed and reflected on theories and practice. The objective was to introduce and prepare pre-service teachers to the three moments of reflective practice, 
as well as to explore their knowledge and beliefs about language teaching methodologies. Some questions prompted students to collaboratively identify and contrast some concepts, then to reflect on the actions taken by the teacher in that case and the actions they would take in the three moments of reflection, and finally to discuss them with other participants of the VLC. Table 3 shows the questions asked for the reflective moments.

Table 3. Questions asked for each reflective moment in the first scenario of the VLC

\begin{tabular}{|c|c|}
\hline Scenario 1 & Questions \\
\hline Activity 3 & $\begin{array}{l}\text { Read the case again and write your reflection based on the following stages and } \\
\text { questions. } \\
\text { 3a: Reflection in action } \\
\text { Why do you think this teacher decided to explain the grammar explicitly? } \\
\text { Why do you think he spent too much time explaining grammar, but a little time in the speaking } \\
\text { activity? } \\
\text { Why did he decide to change his methodology and techniques? } \\
\text { 3b: Reflection on action } \\
\text { Once the class finished, this young teacher reflected on the class. What do you think his answers } \\
\text { are for the following questions? } \\
\text { - Did students understand the use of have got? } \\
\text { - How can I better control the time? } \\
\text { - } \quad \text { Did students learn and enjoy the class? } \\
\text { 3c: Reflection for action } \\
\text { If you were this young teacher, how would you plan your class next time, and what would you do } \\
\text { in class, bearing in mind the problems you could have? }\end{array}$ \\
\hline
\end{tabular}

Source: Own Creation

The second scenario centered on pre-service teachers' reflecting on their own beliefs and practice. With this in mind, each participant analyzed, reflected and contrasted a lesson plan and a video recording from a class he or she had taught. In this way, they could contrast their beliefs with their practice, as well as reflect on their actions in the three moments of the reflection. The questions asked for each reflective moment are shown in table 4. 
Table 4. Questions asked for each reflective moment in the second scenario of the VLC

Scenario 2

Scena

Activity 3

Based on your lesson plan and class, answer the following questions.

3a: Reflection in action

While you were in your class:

Did you do something different to what you had planned? Why?

How did you react to unexpected situations?

How did you feel using the methodology and techniques you selected?

\section{3b: Reflection on action}

If something did not work in class, why didn't it work?

Could you apply the methodology and techniques as you plan? If not, why?

3c: Reflection for action

What would you do the next time in a future lesson, bearing in mind the problems you could have in terms of
a. planning?
b. applying language teaching methodologies and techniques?
c. classroom management?

The last scenario invited pre-service teachers to analyze, reflect, dialogue, and contribute to another pre-service teacher's practice through analyzing the lesson plans and classes recorded. As in the previous scenario, pre-service teachers were asked to identify some key issues in their classmates' lesson plans and videos about language teaching methodology, and to use the three moments of reflection to contribute to their classmates' practice. The questions for each reflective moment were the same as in scenario 2 .
To complete the praxeology prospective-stage, a focus group with six pre-service teachers was assembled after they completed their participation in the VLC. The questions focused on assessing their participation and contributions to the VLC, and recognizing what they learned from their own reflection and others' practices in terms of language teaching methodology. Some of the questions asked in the focus group are shown in table 5. 
Table 5. Questions Asked in the Focus Group

\begin{tabular}{|c|c|}
\hline & Questions \\
\hline Learning from the community & $\begin{array}{l}\text { 1. What did you learn from your classmates' lesson plans and classes? } \\
\text { 2. Do you think the comments made by your classmates to your lesson plans and classes } \\
\text { contributed, in any way, to your practicum and knowledge? } \\
\text { 3. Based on your classmates' answers and practices, what aspects of your practice would } \\
\text { you like to modify? Why? }\end{array}$ \\
\hline Reflection & $\begin{array}{l}\text { 1. Do you think the three reflective moments contribute to your knowledge and practice? How? } \\
\text { 2. When you reflected, which aspects did you focus more on? }\end{array}$ \\
\hline
\end{tabular}

Source: Own Creation

\section{Participants}

The participants involved in this project were chosen on a voluntary basis. They were 25 pre-service teachers from an undergraduate program in English Language Teaching at a private university in Bogotá, Colombia. This bachelor program has nine semesters and offers four areas for teaching formation: Pedagogy, Linguistics, Languages, and Didactics and Methodology. During the seventh semester, students have the possibility to start their teaching practice in public or private institutions where they have to complete 64 hours of teaching during the semester.

To complement their teaching formation process, the participants attend a face-to-face class called Practicum 1. In this class, they discuss classroom management issues, share experiences about critical incidents, revise syllabi, and design material. Their English level varied between $\mathrm{B} 1+$ and B2. All the participants had knowledge about the different methods and approaches to teach English, because they had taken classes on theoretical approaches, didactics, and teaching methodology in previous semesters.

\section{Data Analysis}

In general terms, the answers given by the pre-service teachers in each of the scenarios of the VLC and the ones given in the focus group were analyzed using the stages suggested by Johnson and Christensen (2008): segmenting, coding, and developing categories. It is worth mentioning that the codes and categories emerged from the raw data. Initially, the questions regarding the three reflective moments in each scenario were organized in an Excel sheet. Then, color coding was used in order to identify inductive codes, which can be defined as

"codes that are generated by the researcher by directlyexamining the data during the coding process" (Johnson and Christensen, 2008, p. 775).

Finally, the findings were organized into four main categories which are summarized in the figure below. 


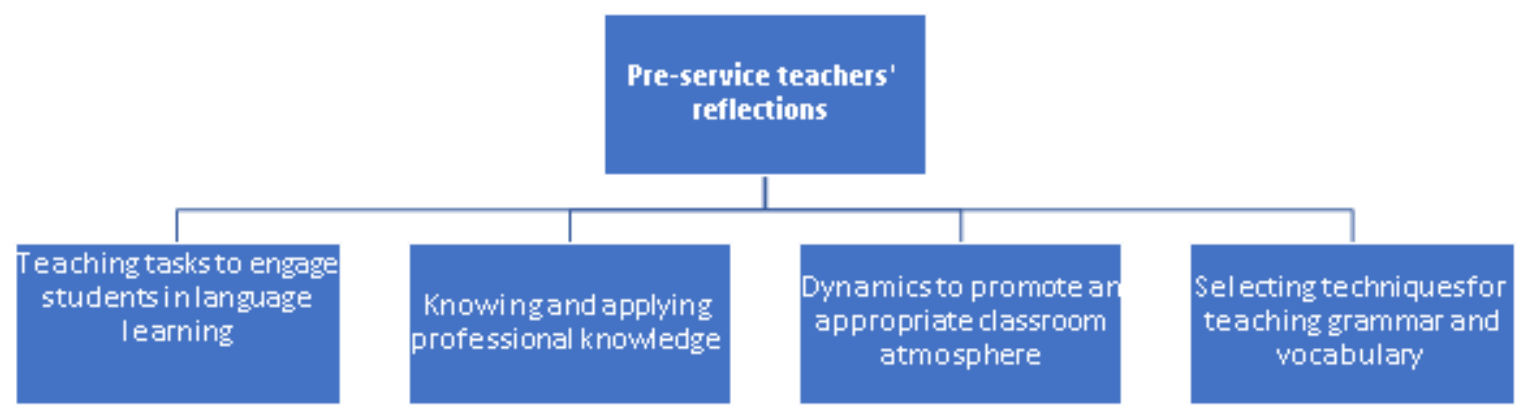

Figure 3. Pre-service teachers' reflections about language teaching methodology

Source: Own creation

Once the information was categorized, the recording from the focus group was transcribed and analyzed using ATLAs.ti. There, codes related to the previously established categories were identified and finally added to each category in the Excel sheet.

\section{Results}

The implementation of the VLC demonstrated four main issues in which pre-service teachers reflected on the three reflective moments. For the reflections excerpted below, the participants are called Student 1 , Student $2 \ldots$, to guarantee confidentiality.

\section{Teaching Tasks to Engage Students in Language Learning}

One of the most recurrent issues pre-service teachers reflected on was the type of activities they used to support students' learning, since they considered that interesting and attractive activities might help students acquire the knowledge taught and get involved in the class. In this sense, the selection of the topic and type of activity was the key to success, as Student 6 wrote: "I would like to make a reading, but with the current social context or something that is particular and funny to read; for example, The Simpsons are a good way to introduce students because they are something that they usually like".
This reflection displays pre-service teachers' concern about motivating and engaging students in learning. It means that reflections tend to focus on finding the best teaching tasks and materials that guarantee students' success.

Regarding the type of activities, the pre-service teachers concluded that activities must be catchy and known by the students in order to get their attention and interest. This was the case with Student 2, who wrote in his reflection in-action: "I could apply a poem that they enjoy to engage them more with the class. Poetry related to the age of the students and based on that teach them what poetry is and its characteristics".

This reflection evidences they are mainly worried about improving their own teaching performance to guarantee students' learning. To achieve this, they are aware the teaching tasks should include students' preferences and not their own. However, the changes pre-service teachers propose to the teaching tasks are mainly based on their own questioning; they do not try to explore other's opinions or theories to find solutions to their concerns.

Another important issue that pre-service teachers reflected on was the appropriateness of the activities for each stage of the class. In some cases, they realized that they should have changed the 
activity or presented it in a different way, since they felt it did not work as they expected. One of the stages they were the most concerned about was the warm-up, especially if they felt it did not fulfill the objective of engaging the students in the class. This is evident in the following extracts from their reflections:

I think that my warm-up activity could have been a little bit more interactive because I feel that it is cool for students, but it does not allow them to have a moment of interaction. Additionally, I feel that this activity fosters the use of Spanish in the class if you don't control it properly. (Student 3)

For the next lesson, I would improve the activities for the warm-up, I noticed that during this stage my students show interest and they work well in the rest of the class. I need to catch their attention from the beginning. (Student 4)

These reflections reveal how pre-service teachers are worried about involving students in a comfortable and communicative atmosphere from the beginning of the class. Although this reflects preservice teachers' worries for motivating students, it also shows they tend to focus their reflection on problems they have on their own teaching performance: it means they tended to reflect on technical issues regarding language teaching

\section{Knowing and applying professional knowledge}

Two tendencies were identified in the methodologies participants use, or think they should use, to enhance students' language learning: the communicative approach and traditional methodologies, such as the audiolingual method or Total Physical Response. Regarding the first trend, some pre-service teachers pointed out in their reflections that communication must be the key aspect when selecting an approach or methodology, since they believe language is functional and learning should be promoted through real and meaningful communicative activities (Richards and Rogers, 2014).
This was especially evident in the third scenario, when pre-service teachers were asked to reflect on their classmates' practices. After reading and observing some classmates' lesson plans and classes, Student 3 concluded that his classmate could have implemented a different approach which enhanced interaction and communication, since the activities used focused more on repetition and memorization of words. Participants like Student 3 usually "recommended" applying communicative approaches, such as experiential learning and/or task-based learning:

If I were my partner, I would probably rethink the way the class was proposed. I personally prefer a more interactive and more communicative approach in which students interact more between them. So, in the part where the teacher asked students for their pets, I would ask them to ask their partners, in order to make a Student-Student activity and not a Teacher-Student activity.

The reflections based on other pre-service teachers' practices show that it is easier to reflect on professional knowledge based on other's experiences rather than on their own. They tend to be more critical to others' practices in terms of how the knowledge is applied in the teaching tasks.

In this sense, the pre-service teachers perceive the importance of enhancing communication in the classroom and are aware of some principles of the communicative approach. Nevertheless, when they reflected on their own practice or on the hypothetical case, they concluded that traditional methodologies are considered a good alternative to guarantee students' learning. This reveals that pre-service teachers have a functional view of language (Richards y Rodgers, 2014) because they believe language classes should focus on teaching vocabulary and forms. Moreover, it is evident that in spite of the fact that pre-service teachers possess professional knowledge about language teaching, they have some difficulties applying that knowledge in their own planning and in the decisions they make in the classroom.

Even among pre-service teachers who have studied different methodologies and approaches, 
and who have had the chance to design classes using communicative approaches (especially task-based approaches) during their training, and recognize the aim of classes should be promoting communication, there is still a tendency to believe that memorization and teaching grammar are the main components of language classes. This might be the result of being exposed to this type of teaching in different learning contexts for a long time, which can make students believe this is the best way to teach and learn (Gamboa et al., 2018), and make that trend a fundamental part of their teaching knowledge.

\section{Dynamics to Promote an Appropriate Classroom Atmosphere}

When teachers want to preserve a suitable atmosphere in the classroom, they think about classroom management strategies to organize students, time, materials, and space (Sieberer-Nagler, 2016). In the case of these pre-service teachers, during their first teaching experiences they reflected on maintaining an appropriate classroom atmosphere, bearing in mind two main aspects: time and discipline.

On one hand, they were mainly concerned about the time spent in each activity, keeping in mind that a given activity sometimes took up more time than it was planned. This might be the result of difficulties presented with the devices needed, teacher's talk, discipline, or the level of the activity. Students 1 and 14 highlighted this concern:

If I had been the teacher, I would have followed the instructions in my lesson plan. It will probably be necessary to take time to present the topic, but the purpose should be to organize the time so that each activity can be developed without wasting time or the structure of the class. (Student 1)

I would plan the lesson with activities that do not spend a lot of time during the development of each step of the class, the time will be sufficient for all the activities that I have in mind. (Student 14)

These two reflections indicate that they think carefully about time during their planning, and that in their classes they try to avoid wasting time talking about "useless issues", since the most important thing to them is covering the activities presented. Pre-service teachers also indicated that sometimes they pay little attention to the way students are developing the activity, in terms of difficulty and clearness.

On the other hand, not many pre-service teachers thought about discipline, considering this is not an aspect they should reflect on at the beginning of the teaching practicum. Pre-service teachers have some difficulties seeing themselves as an authority in the classroom, and lack problem-solving skills.

However, when pre-service teachers reflected on discipline, they became aware of the need to find strategies and could develop their problem-solving skills to deal with conflict situations. The following is an example of this type of reflection:

I think that it is so difficult to plan everything perfectly because the issues in a class are unpredictable especially when there are more than 15 students. For example the indiscipline, the classroom management depends on the schedule of the class if the class is at the first-hour students are more receptive but if the class is at the last hour students are tired,[...] So, what I would do or I do is to have a second plan such as flashcards of the topic to replace the video, or a control drill activity about the topic to practice speaking about the topic and to control indiscipline I have a monitor who can do a dictation of the topic while I talk with students who don't pay attention. (Student 14)

Although some participants were aware of controlling discipline and others of timing to guarantee all the activities are carried out, their reflections show little evidence of analysis of discipline problems and lack of problem-solving skills that help them deal with classroom management difficulties. Instead, the reflections showed that they are more worried about completely developing the activities proposed in the lesson plan. There is a lack of consciousness of recognizing themselves as authority in the classroom to preserve a suitable atmosphere which promotes effective language learning. 


\section{Selecting Techniques for Teaching} Grammar and Vocabulary

Given that most of the participants were taking the Didactics course at the same time they were doing their first practice, they were keenly aware of the techniques for teaching the language components, especially grammar and vocabulary. Regarding the reflections about grammar, the implementation of inductive and deductive techniques was questioned. They mainly thought about the way other pre-service teachers did it.

Approximately half of the pre-service teachers reflected on the need to explain grammar inductively, since with this technique, students develop higher thinking skills when they discover the rule by themselves. However, their reflections on their own practice did not evidence any thoughts about the way they presented this language component. On this matter, Student 13 reflected:

Teaching with the inductive method can be complicated, students are used to learning with the deductive method, however, you have to create activities that provide these examples. A text can be a good option, so in this case, it is better for students to extract the examples of the text provided, it is necessary to fill them with examples not only with reading, it is necessary to provide images, videos, and a good game. (Student 13)

Contrary to this idea, other participants considered mandatory to explain the rules explicitly, believing that students need to be completely aware of the rules to be able to complete exercises. Student 14 said so directly: "I would plan the proposed lesson, starting with the deductive method where the students get to know the rules of the subject."

Based on this reflection, it is evident that some pre-service teachers still design their classes by thinking of the way to introduce each form, without considering any meaningful context, an approach, or even other techniques to present grammar such as through texts, stories, songs, and situations (Thornbury and Harmer, 2012).

This evidence shows that even the Didactic and Methodology classes emphasize on making pre-ser- vice teachers aware of the communicative function of language, they still tend to design their classes based on grammar structures. This reflects that the knowledge they are constructing and applying about teaching is primarily based on empirical learning that results from the interactions with other teachers and learners, and as a consequence the theoretical learning becomes decontextualized and irrelevant at the moment of planning and teaching.

For the theoretical knowledge being used during the practicum, Johnson and Golombek (2011) suggest mediation as a strategy to promote reorganization and reconceptualization between what pre-service teachers have learnt from the social interaction and theory.

Moving on to the pre-service teachers' reflections on techniques to teach vocabulary, they primarily reflected on the use of images or flashcards as a way to introduce vocabulary. This was mainly evidenced in the hypothetical case presented in the first scenario of the VLC. They questioned the application of the matching activity, because pre-service teachers tended to use images or flashcards instead of other techniques proposed by Thornbury and Harmer (2013), such as realia, webs, games, and so on. With this in mind, Student 6 wrote:

To introduce the vocabulary, I would like to try something with images like flashcards, to provide them the drawing and how it is named. With this, they will make a relationship between the draw and the vocabulary and this vocabulary will be easier to remember that a matching activity at the beginning. (Student 6)

It is also evident in this extract that pre-service teachers centered their attention on how to present the vocabulary, not on how to practice it. This means they were inclined just to present the words, but they did incorporate a few activities that allow students to practice the vocabulary in context. Additionally, just as happened with the techniques for teaching grammar, in the other two scenarios of the VLC, there was little reflection on the way they and their classmates presented or practiced vocabulary in 
their classes, since they worried about preparing activities instead of joining and connecting them.

\section{Discussion}

Four significant aspects of the reflections made by the pre-service teachers in the VLC will be discussed in this section. Firstly, VLC contribute to participants' reflection on their own beliefs and practice, increasing their knowledge about language teaching methodology in the light of other experiences, since they can compare the decisions made and analyze the possible solutions they would give to the situations stated.

In this process, they questioned their own beliefs and, as Olaya (2018) concluded in her study "Reflective teaching: An approach to enrich the English teaching professional practice", they opened their minds and rearranged their lessons. However, while Olaya (2018) found that pre-service teachers can update their methodologies, in this case, it seemed the participants were more aware of certain methodological aspects, mainly about techniques for teaching grammar and vocabulary, rather than trying to update their knowledge. It also evidences that pre-service teachers' reflections are located in a low level of critical reflection, since they tend to describe and find solutions to technical teaching problems mainly.

To bring about changes in their methodologies, as Olaya (2018) affirmed, would require more time and effort to reflect. Even though these pre-service teachers had enough time to develop the reflective activities in the VLC, they were not completely autonomous in doing them. As a result, they answered the reflective questions on the last day they were due. In this sense, it is noticeable that this process needs to be guided and supported by the tutors, with the purpose of enhancing pre-service teachers' autonomy, and increasing self-reflection. Thus, eventually, they will be conscious about their practices and decisions, and may include adjustments or changes in their methodologies.

A second significant aspect is that pre-service teachers were more aware about language teaching methodology theory, since they were able to describe the techniques used to teach grammar and vocabulary. This shows they better understand how learners learn, and in this why they constantly look for more effective teaching strategies and activities. This finding agrees with Olaya (2018), who concluded that being conscious of what teachers are doing in the classroom enhances effective language education, and in this way improves students' results.

Even though the pre-service teachers were aware of the aforementioned techniques, knew the importance of promoting communication in the language classroom, met students' needs, and recognized the principles of the communicative approach, they had some visible difficulties reflecting on the approach they used and why they implemented it. This shows that up to this moment pre-service teacher's reflections are not very complex, since they basically describe technical teaching issues, and evidence a lack of inquiry and discussion that allow them to transform their practice and understand the actions they should take in the classroom.

Moreover, this indicates that past experiences as learners become the base for planning and teaching, which means pre-service teachers' learning comes from their participation in social practices of teaching and learning (Johnson, 2009), and in their first teaching experiences they tend to prioritise the knowledge acquired through social experiences rather than the theories studied in the Didactics classes. Nevertheless, continuous reflection and participation in different kind of communities might contribute to transform and reconstruct their knowledge and practice.

Another important finding is related to the level of reflection pre-service teachers showed in the VLC. According to Van Manen (1977), there are three different levels of reflection. The data revealed that the pre-service teachers reached the first and second levels, but none of them reached the third. The first level "refers to the technical application of educational knowledge" (Van Manen, 1977, p. 226). The participants reflected on this level, since they were concerned about the different methodologies to be 
implemented in order to help their students develop their language skills. While some of them were promoting interaction and communication, and they suggested applying communicative approaches such as experiential and/or task-based learning, others stated that traditional methodologies could be good alternatives to ensure students' learning. This level of reflection was also evident when the pre-service teachers evaluated the effectiveness of the different techniques they used to teach grammar.

The second level of reflection has to do with the process of understanding the educational experience to make practical choices (Van Manen, 1977). The pre-service teachers reached this level when they were aware of the different dynamics a class has, such as classroom and time management, materials and space, and the decisions they had to make when implementing their lessons according to those dynamics. Participants were conscious at the moment of reflecting in and on action, allowing them to notice the importance of the factors that influence the teaching and learning processes. Their experiences were useful, so they could take account of those situations to improve their future action, to think in depth for that action. The final level of reflection, in Van Manen's (1977) view, requires deep analysis, and a critical perspective on the socio-political nature of education. Unfortunately, the pre-service teachers in this study have not reached yet that level.

Finally, the fourth aspect to discuss is a notable lack of awareness of classroom management. Based on the pre-service teachers' answers, they were more worried about preparing interesting activities for their students, than about engaging them in their classes. An opposite situation was found in the research conductec by Hoyos et al. (2017), which showed that classroom management and indiscipline were issues that concerned pre-service teachers and influenced the choice of activities they developed. As those participants were facing difficult situations in relation to discipline control, they noticed that they had to make choices regarding the kind of activities proposed. In contrast, even though the pre-service teachers in the current project recognized classroom management as a relevant factor influencing their lessons, their reflections did not include specific strategies or proposals to overcome it. Data revealed they were more committed to the fulfillment of the activities rather than to the promotion of a proper learning environment.

\section{Conclusions}

As stated, the main purpose of this article was to report the analysis carried out to 25 pre-service teachers' reflections regarding language teaching methodology. To facilitate their participation and promote interaction, a VLC was created, providing different questions in order to allow them to reflect about their first experience in their teaching practicum.

Based on the analysis of the pre-service teachers' reflections in the VLC in the three in-on-for moments, different aspects should be emphasized. First, it is necessary to continue strengthening the connection between theory and practice through the reflective process. It is noteworthy that the more rigorous reflections pre-service teachers develop, the more aware they can be about their practice. In this reflective process, the theory and conceptualization they had already internalized might be used consciously to plan lessons with a clear basis and the proper methodologies.

Second, as leaders and tutors, we should accompany this process, promoting spaces that facilitate formal reflection while students are in their training process, and providing the necessary tools to guide that connection between theory and practice. For instance, it would be fundamental to adjust the form model pre-service teachers are using to plan their lessons, in order to provide them with different versions that fit the approach they want to implement. This change will eventually help them recognize and properly use different methodologies, bringing benefits for their students and boosting their learning process.

The third remarkable issue to consider is the need to help pre-service teachers reach a higher level of reflection. As it was explained, pre-service teachers' 
reflection focused mainly on technical teaching issues, and rather than a critical reflection it was a description of problems or situations experienced. Regarding this, it is relevant to highlight the role bachelor programs play in this process, since they are the ones responsible for providing future teachers with the elements and strategies needed to develop critical thinking. In this sense, there could be an opportunity for language teaching programs to include in their classes more reflective activities that promote self-awareness, recognize pre-service teachers' strengths and weaknesses, and contribute to construct or reconstruct knowledge about language teaching. Thus, it is possible to support teachers' first teaching experience and to promote a more critical reflection on the way they are teaching and the methodologies and approaches implemented in their practicum.

Lastly, this study showed the use of VLC as an innovative and useful resource that offered pre-service teachers not only an alternative way to express themselves about their concerns, feelings, and beliefs about teaching, but also interact with peers that are facing similar situations in order to reflect, build knowledge and learn through their contributions.

\section{Referencias}

Alirio Insuasty, E. \& Zambrano Castillo, L. C. (2010). Exploring reflective teaching through informed journal keeping and blog group discussion in the teaching practicum. Profile Issues in Teachers' Professional Development, 12(2), 87-105.

Becerra Traver, M. T., \& Gutiérrez Esteban, P. (2016). Necesidades formativas del alumnado universitario a partir del análisis de sus Entornos Personales de Aprendizaje. RIITE Revista Interuniversitaria de Investigación en Tecnología Educativa, (1). https:// doi.org/10.6018/riite/2016/271971

Bozu, Z. \& Imbernon-Muñoz, F. (2009). Teaching portfolios as a formative strategy for a reflective practice on beginner university professors. Revista d'Innovació i Recerca En Educació, 2(2), 61-73. 10.1344/reire2009.2.2224

Coll, C., Bustos, A. \& Engel, A. (2008). Las comunidades virtuales de aprendizaje. In C. Coll y C. Monereo (eds.), Psicología de la educación virtual (pp. 299320). Morata.

Cote Parra, G. E. (2012). The role of reflection during the first teaching experience of foreign language pre-service teachers: An exploratory-case study. Colombian Applied Linguistics Journal, 14(2), 24-34.

Farrell, T. S. (2013a). Reflective teaching. TESOL International Association.

Farrell, T. S. (2013b). Reflective writing for language teachers. Equinox.

Farrell, T. S. (2015). Reflective language teaching: From research to practice. Bloomsbury Publishing.

Farrell, T. S. (2018). Reflection- "as"-Action in ELT. ELT Development Series. TESOL Press.

Gairín, J. (2006). Las comunidades virtuales de aprendizaje. Educar, 37, 41-64. http://www.raco.cat/index. php/educar/article/viewFile/58020/68088

Gamboa, A., Cuervo, L. \& Herrera, C. (2017). La observación y narración autobiográfica: un camino hacia la construcción de la identidad profesional docente. In A. León (Ed.), VII Semana: Historias, saberes y prácticas educativas innovadoras e incluyentes (pp. 67-76). Corporación Universitaria Minuto de Dios.

Gamboa, A., Cuervo, L., Herrera. C. \& Lalle, C. (2018). Teachers' identity formation: An insight into pre-service teachers. In Ministerio de Educación Superior y las universidades de la República de Cuba (Eds.), Memorias del 11. ${ }^{\circ}$ Congreso Internacional de Educación Superior. Ministerio de Educación Superior y las universidades de la República de Cuba.

Hennissen, P., Beckers, H. \& Moerkerke, G. (2017). Linking practice to theory in teacher education: A growth in cognitive structures. Teaching and Teacher Education, 63, 314-325.

Hoyos Ensuncho, M., González Luque, L. A. \& Ortiz, M. (2017). Reflexiones de los docentes de inglés en formación sobre su práctica pedagógica. In Corporación Universitaria Minuto de Dios (Eds.), Memorias de investigación (pp. 1-9). Corporación Universitaria Minuto de Dios.

Johnson, B. \& Christensen, L. (2008). Educational research: Quantitative, qualitative, and mixed approaches. Sage.

Johnson, K. E. (2009). Second language teacher education: A sociocultural perspective. Routledge.

Johnson, K. E. \& Golombek, P. R. (2011). A sociocultural theoretical perspective on teacher professional 
development. In Johnson, K. E. and Golombek, P. R. (Eds.), Research on second language teacher education: A sociocultural perspective on professional development. Routledge.

Juliao Vargas, C. G. (2011). El enfoque praxeológico. Corporación Universitaria Minuto de Dios.

Lee, I. (2007). Preparing pre-service English teachers for reflective practice. ELT Journal, 61(4), 321-329.

Morrison, K. (1996). Developing reflective practice in higher degree students through a learning journal. Studies in Higher Education, 21(3), 317-332. https:// doi.org/10.1080/03075079612331381241

Murua Anzola, I., Cacheiro González, M. L. \& Gallego Gil, D. J. (2014) Las cibercomunidades de aprendizaje (cCA) en la formación del profesorado. Learning Cybercommunities in Teacher Training. Revista de Educación a Distancia (RED), (43), 12-29.

Olaya Mesa, M. L. (2018). Reflective teaching: An approach to enrich the English teaching professional practice. HOW Journal, 25(2), 149-170. https://doi. org/10.19183/how.25.2.386

Raposo-Rivas, M. \& Escola, J. (2016). Comunidades virtuales de aprendizaje: Revisión de una década de producción científica hispano-lusa. Journal for Educators, Teachers and Trainers, 7(2), 11-24.

Richards, J. C. \& Rodgers, T. S. (2014). Approaches and methods in language teaching. Cambridge University Press.

Schön, D. A. (1987). Educating the reflective practitioner: Towards a new design for teaching and learning in the profession. Jossey-Bass.

Sieberer-Nagler, K. (2016). Effective classroom-management and positive teaching. English Language Teaching, 9(1), 163-172.

Tilson, J., Sandretto, S. \& Pratt, K. (2017). Connecting theory to practice: Using preservice teachers' beliefs, theories and video-recorded teaching to prompt a cycle of praxis. Teaching and Teacher Education: An International Journal of Research and Studies, 67(1), 454-463.

Thornbury, S. \& Harmer, J. (2012). How to teach grammar. Pearson Education.

Thornbury, S. \& Harmer, J. (2013). How to teach vocabulary. Pearson Education.

Van Manen, M. (1977). Linking ways of knowing with ways of being practical. Curriculum Inquiry, 6(3), 205-228. doi.org/10.1080/03626784.1977.11075533
Viáfara, J. J. (2005). The design of reflective tasks for the preparation of student teachers. Colombian Applied Linguistics Journal, 7, 53-74.

Walsh, S. \& Mann, S. (2015). Doing reflective practice: A data-led way forward. ELT Journal, 69(4), 351-362. https://doi.org/10.1093/elt/ccv018

Zahid, M. \& Khanam, A. (2019). Effect of reflective teaching practices on the performance of prospective teachers. тојет: The Turkish Online Journal of Educational Technology, 18(1). http://www.tojet.net/ articles/v18i1/1814.pdf 
